\title{
Peningkatan Produksi Aneka Camilan Dan Pengenalan Pencatatan Akuntansi (Program Pengabdian Masyarakat Pada UMKM "Dua Bersaudara"-Pembuatan Produk dan Pencatatan Akuntansi)
}

\author{
Nur Suci IMM. ${ }^{1}$, Djuwari ${ }^{2}$, Dewi M. ${ }^{3}$ \\ STIE Perbanas Surabaya \\ e-mail: ${ }^{1}$ nursuci@ perbanas.ac.id, ${ }^{2}$ djuwari@ perbanas.ac.id, ${ }^{3}$ dewi.murdiawati@perbanas.ac.id
}

\begin{abstract}
Abstrak
Sebuah desa yang bernama Tambak Oso berada di Kecamatan Sedati, Kabupaten Sidoarjo merupakan daerah tambak. Di sebelah utaranya, daerah ini merupakan perbatasan dengan Kota Surabaya. Di desa ini pula, terdapat sebuah UMKM yang cukup besar yaitu UMKM "Dua Bersaudara" yang merupakan UMKM pindahan dari daerah Mojokerto. Tujuan dari pengabdian masyarakat ini adalah memberikan pelatihan pembuatan snack stick krispi/kering dengan bahan baku dasar berupa tepung, dan pelatihan pencatatan akuntansi secara sederhana berbasis Pernyataan Standard Akuntansi Keuangan Entitas Mikro Kecil Menengah (PSAK EMKM). Metode pengabdian yang dilakukan berupa pelatihan dan memberikan sharing knowledge terkait pencatatan akuntansi secara sederhana. Ringkasan hasil dari kegiatan abdimas ini adalah : memberikan pelatihan pembuatan snack stick kering dengan bantuan seorang Pelatih dan dilakukan pendampingan sehingga bisa proses sendiri dengan menggunakan cetakan yang diberikan oleh tim abdimas. Selain itu memberikan sharing knowledge yaitu memberikan siklus atau sistematika pencatatan akuntansi secara sederhana dan menggunakannya secara manual dalam pencatatan transaksi. Sebagai saran yang diusulkan, bahwa program abdimas ini masih bisa dilanjutkan untuk program berikutnya, terutama terkait dengan pencatatan akuntansi khususnya pencatatan akuntansi antara kantor pusat dan kantor cabang. Hal ini dikarenakan, Mitra telah membuka cabang di Banyuwangi dan Jember.
\end{abstract}

Kata Kunci: UMKM, Pencatatan akuntansi, snack stick krispi/kering, PSAK EMKM

\section{PENDAHULUAN}

Nama Desa Tambak Oso mengingatkan kita kepada legenda yang dikenal dengan sebutan Sarip Tambak Oso. Sebutan itu merupakan nama pemuda kampung yang tinggal di wetan (bahasa Jawa yang berarti timur) sungai Sedati Sidoarjo. Dia dikenal sebagai seorang pendekar yang bertemperamen kasar tetapi sangat perhatian pada penderitaan orang-orang miskin yang menjadi korban pemungutan pajak oleh Belanda. Desa Tambak Oso berada di perbatasan antara Surabaya Timur dan Sidoarjo. Sebuah desa dekat dengan tol Juanda, hutan mangrove, dan laut utara yang kaya akan sumberdaya alamnya. Sebenarnya, terdapat beberapa potensi yang ada di Tambak Oso, antara lain pariwisata berupa daerah pemancingan yang dilengkapi dengan wisata kuliner. Tambak Oso mempunyai lokasi yang bagus untuk diberdayakan sebagai daerah wisata, di samping udaranya yang segar serta alamnya yang banyak berupa persawahan. Di sana, juga sudah berkembang wisata pemancingan yang sudah lama berdiri di pesisir sungai sepanjang mangrove. Tambak Oso juga mempunyai potensi sebagai desa kuliner, menginggat masyarakat Tambak Oso juga merupakan daerah yang masyarakatnya beberapa memiliki kegiatan UMKM.

Pada kegiatan abdimas yang dilakukan dipilihlah salah satu usaha mikro kecil dan menengah (UMKM) yang terdapat di daerah Tambak Oso yaitu UMKM "Dua Bersaudara". Permasalahan yang ada pada UMKM "Dua Bersaudara" (mitra) ini adalah : Pertama, terkait dengan pencatatan akuntansinya, belum dilakukan. Mitra hanya mengumpulkan nota/kwintansi dari kegiatan pembelian yang dilakukan dan tembusan/copi Nota dari hasil penjualannya. Pencatatan akuntansi secara sederhana saja belum dilakukan apalagi Laporan Keuangan belum disusun. 
Permasalahan yang kedua, adalah terkait dengan cara dan trik pembuatan produk camilan yang baru bagi Mitra yaitu Stick Kering aneka rasa. Produk camilan ini sebenarnya sudah ada, namun tidak diproduksi sendiri tetapi dibeli dari pihak lain dan kualitasnya tidak begitu bagus juga atos tidak renyah. Sedangkan yang diinginkan Mitra adalah berupa Stick kering yang gurih dan renyah. Alasan mengapa Mitra berkeinginan untuk bisa memproduksi sendiri camilan stick kering, karena camilan ini bnyak pembelinya. Selain itu Mitra juga berharap tatkala memproduksi sendiri maka laba dari penjualan yang didapatkan akan lebih banyak. Stick kering merupakan salah satu camilan yang termasuk omzet yang menjanjikan, karena banyak laku dijual.

Sebenarnya camilan yang dijual oleh Mitra beraneka ragam jenisnya, namun hanya satu produk saja yang diproduksi sendiri, yaitu usus goreng dan camilan ini merupakan produk unggulannya. Sedangkan camilan yang lain sebagian besar dibeli dari pedagang yang lain, kemudian dikemas sendiri menjadi kemasan yang lebih kecil. Sementara terdapat satu produk camilan yang laku keras penjualannya, namun bukan merupakan produksi sendiri, tetapi dibeli dari UMKM yang lain yaitu camilan Stick kering. Mitra menginginkan adanya tambahan produk camilan berupa aneka stick kering, agar bisa melakukan proses produksi sendiri. Hal ini disebabkan karena masih dilakukannya pembelian produk dari pihak lain selama ini, juga dari sisi kualitas, produk stick kering yang dibeli jadi, juga kurang bagus. Mitra berharap dapat memproduksi sendiri camilan stick kering tersebut, dengan kualitas yang lebih dan harga terjangkau.

Tujuan yang akan dilakukan dalam pengabdian kepada masyarakat ini adalah berupa program pendampingan pencatatan akuntansi secara sederhana pada produk hasil camilan kering, serta cara pembuatan jenis snack stick kering aneka rasa yang penjualannya cukup bagus.

\section{METODE PENGABDIAN}

Metode Pengabdian ini merupakan paparan yang berisi waktu dan tempat Pengabdian, metode, dan rancangan, pengambilan sampel, dan teknik analisis data serta hal-hal lain yang berkaitan dengan cara Pengabdian.

\subsection{Waktu dan Tempat Pengabdian}

Pengabdian kepada masyarakat (Abdimas) ini dilaksanaan antara bulan September 2019-April 2020. Pengabdian kepada masyarakat ini dilakukan di Desa Tambak Oso berada di perbatasan antara Surabaya Timur dengan Sidoarjo. Sebuah desa dekat dengan tol Juanda, hutan mangrove dan laut utara yang kaya akan sumberdaya alamnya.

Tepatnya pengabdian kepada masyarakat ini dilakukan di UMKM "Dua Bersaudara”, dijalan Tambak Oso Kampung Baru no.114 Sidoarjo.

\subsection{Metode dan Rancangan Pengabdian}

Metoda pelaksanan Abdimas internal ini, berupa aktivitas-aktivitas yang terkait dengan permasalahan yang dialami oleh Mitra, yang akan dilaksanakan selama kurun waktu sembilan bulan ini terdiri dari berbagai jenis aktivitas, diantaranya :

\subsubsection{Tahapan Awal}

1. Diskusi dan komunikasi dengan Pemilik, terkait dengan pelaksanaan kegiatan diantaranya:

a. Jadwal Kegiatan dan tempat kegiatan

b. Koordinasi dengan Pelatih dan Tim Abdimas.

c. Persiapan Pelaksanaan (Peralatan yang dibutuhkan Mitra, peralatan untuk pelatihan, spanduk, konsumsi, transportasi, honorarium cenderamata, koordinasi dengan bagiat terkait)

Partisipasi aktif dan kerjasama yang diharapkan diberikan antara lain berupa :

1. Kesediaan melakukan diskusi dengan baik bersama tim pelaksana Abdimas terkait dengan pelatihan yang akan dilaksanakan. 
2. Menyediakan sarana dan prasarana (fasilitas) yang akan digunakan untuk diskusi, pelatihan, dan pendampingan.

3. Kesediaan mengikuti kegiatan hingga selesai dan bersedia menerapkan hasil program ini sebagai kebermanfaatan dalam kehidupan bermasyarakat.

\subsubsection{Tahapan Pelaksanaan}

a. Pelatihan pembuatan aneka snack stick aneka rasa, untuk dapat memberikan cara pembuatan, resep-resep yang bisa dilakukan. Manfaat dari kegiatan ini adalah untuk memberikan trik-trik pembuatan stick kering yang memberikan hasil camilan yang enak dan berkualitas, agar bisa bersaing.

b. Memberikan sharing knowledge dengan memberikan pelatihan tentang pencatatan akuntansi secara sederhana namun informative, transparan, dan akuntabilitas (Liliane, P., \& Colette, G. 2009). Selain menjaga transparansi dan akuntabilitas, perlu juga ada monitoring dan evaluasi dalam hal akuntansi yang bertujuan untuk misalnya memisahkan pencatatan individu dan perusahaan (Mindhayani, I. Dkk, 2019).

Untuk kegiatan monitoring dalam kegiatan ini harus ada sasarannya. Adapun sasarannya adalah terutama pemilik UMKM, karena pencatatan akuntansinya ditangani sendiri. Manfaat dari kegiatan ini adalah untuk memberikan wacana bagi pemilik agar dapat menghasilkan pencatatan keuangan yang layak.

c. Peran dan kontribusi mitra. Seluruh rencana kegiatan ini tidak dapat berjalan lancar tanpa dukungan dan partisipasi pemilik dan pekerjanya.

\subsubsection{Tahapan Monitoring dan Evaluasi}

Monitoring dan evaluasi merupakan kunci untuk menjaga keajegan kualitas produk (Zorpas, A. A., Lasaridi, K., Pociovalisteanu, D. M., \& Loizia, P., 2018). Proses monitoring dan evaluasi terhadap pelaksanaan program ini dilakukan dengan cara kami mengikuti pembuatan snack stick kering dan pencatatan akuntansinya. Pada tahapan ini, dilakukan monitoring terhadap mitra, terkait dengan pelatihan pembuatan stick kering yang renyah, mitra langsung memproduksinya namun dengan komposisi bahan yang dikurangi dibanding dengan yang diajarkan saat pelatihan. Untuk pencatatan akuntansinya, untuk sementara waktu karena memasuki masa Pandemi, Covit 19, Mitra mengurangi untuk kegiatan monitoring.

\section{HASIL DAN PEMBAHASAN}

a. Memberikan pelatihan kepada Pemilik/Mitra, pembuatan aneka snack stick aneka rasa. Kegiatan ini bertujuan untuk dapat memberikan cara pembuatan, resep-resep stick kering yang bisa dilakukan. Manfaat dari kegiatan ini adalah untuk memberikan trik-trik pembuatan stick kering yang memberikan hasil camilan yang enak dan berkualitas, agar bisa bersaing. Kegiatan ini atas permintaan Mitra, karena untuk camilan ini sebenarnya mitra sudah memiliki dengan cara membeli dari pihak lain. Namun, produknya masih terasa padat atau keras (atos) dan kurang enak. Hal ini yang memotivasi mitra untuk bisa memproduksi sendiri. Setelah selesai pelatihan pembuatan stick kering tersebut, mitra membuat dalam skala kecil dengan menggunakan cetakkan yang dibelikan oleh Tim abdimas dan mulai dipasarkan. Selanjutanya, tim Abdimas melihat sendiri dalam rangka monitoring, hasil produksi stick keringnya bertumpuk dan siap untuk dikirim, untuk memenuhi pesanan.

Hasil produksi stick kering ini memiliki resep sama persis seperti yang diajarkan pada saat pelatihan. Misalnya, komposisi dan bahan sama, namun takaran bahan komposisinya ada yang dikurangi, agar biaya produksinya tidak terlalu mahal. Ini bertujuan agar mereka dapat menjual dengan harga yang tidak terlalu jauh dengan harga jual yang selama ini dilakukan oleh Mitra. Hasil produksi Mitra untuk camilan stick kering ini lebih renyah dan lebih enak dibanding 
dengan produk sebelumnya yang dibeli dari luar.

b. Memberikan sharing knowledge dengan memberikan pelatihan tentang pencatatan akuntansi. Sharing knowledge merupakan kunci untuk menjaga adanya komunikasi ajeg agar dapat meningkatkan kualitas produk yang dicapai (Saffar, N., \& Obeidat, A., 2020). Selain peningkatan mutu produksi, knowledge sharing dalam akuntansi bisa menambah motivasi individu untuk mengekspresikan gagasannya sehingga terjadi tukar menukar pendapat. Yang pada akhirnya, akan mengikuti pendapat yang lebih baik (Gissel, J. L., \& Johnstone, K. M., 2017).

Dalam kaitannya dengan program abdimas ini, kegiatannya dilakukan dengan pemberian pengetahuan tentang bagaimana melakukan pencatatan secara sederhana terkait dengan pencatatan yang sudah dilakukan, mulai dari pencatatan pembelian bahan baku dan bahan-bahan lain yang dibutuhkan hingga penjualannya. Selama ini Mitra hanya melakukan pencatatan tatkala melakukan penjualan untuk skala/partai besar, baik yang di Sidoarjo, Suarabaya maupun di luar Jawa Timur. Penjualan yang dilakukan selain dijual dalam partai besar juga dilakukan penjualan eceran kepada masyarakat untuk kepentingan dikonsumsi sendiri maupun untuk dijual kembali. Penjualan eceran ini kadang tidak dilakukan pencatatan. Padahal selama pengamatan yang kami lakukan, beberapa pembeli datang untuk melakukan pembelian camilan yang dijual oleh Mitra. Selain itu Mitra tidak pernah menghitung secara rinci berapa sebenarnya/tepatnya besarnya harga pokok produksinya.

Memberikan sharing knowledge dengan memberikan pelatihan tentang pencatatan akuntansi secara sederhana namun informatif, transparan dan akuntabilitas. Sasarannya adalah pemilik (Mitra), karena semua catatan dilakukan sendiri oleh Mitra. Manfaat dari kegiatan ini adalah untuk memberikan wacana bagi Mitra agar dapat meghasilkan pencatatan keuangan yang layak. Berdasarkan teori bahwa semua transaksi yang dilakukan dengan pihak lain harus dilakukan pencatatan, sebagai pertanggungjawaban. Metode yang dilakukan dalam memberikan sharing knowledge adalah memberikan siklus atau sistematika pencatatan dan menggunakannya secara manual dalam pencatatan transaksi.

Mitra tidak menyetujui ketika kami menawarnakan untuk sebuah aplikasi pencatatan akuntansi, karena Mitra belum siap untuk peralatannya maupun sumber daya manusianya yang akan menangani catatan akuntansi dengan menggunakan computer dan aplikasi. Tim Abdimas akhirnya hanya memberikan pelatihan secara manual dengan materi bagaimana melakukan pencatatan dan apa sebenarnya pentingnya melakukan pencatatan akuntansi yang dapat menghasilkan Laporan Keuangan. Apalagi saat ini Mitra sedang mempersiapkan pembuakaan cabang di kota Banyuwangi. Setelah diberikan wacana tentang pentingnya pencatatan akuntansi, Mitra mulai tertarik untuk melakukannya. 
c. Monitoring dan Pendampingan

Berdasarkan pendampingan yang dilakukan dan hasil monitoring, dengan pesanan stick kering yang cukup banyak, Mitra akhirnya memutuskan untuk membuat dan memesan cetakan yang volume produksinya lebih banyak dibanding dengan cetakan yang diberi oleh Tim Abdimas. Hal ini dilakukan agar bisa memenuhi pesanan dan jam produksinya tidak terlalu lama. Berdasarkan hasil monitoring juga, Mitra minta bantuan Pelatih untuk mendapatkan dan memesan mesin cetakan stick kering dengan kapasitas yang cukup besar dan cetakan tersebut didapat serta digunakan untuk proses produksi camilan stick kering, dengan hasil memuaskan bagi Mitra

Berikut beberapa foto/gambar pada saat kegiatan abdimas dengan Mitra :

a. Berikut adalah foto saat sharing di tempat Mitra.

Gambar-gambar (foto-foto) berikut ketika Mitra menunjukkan hasil produksi stick kering, dengan resep dari pelatihan.

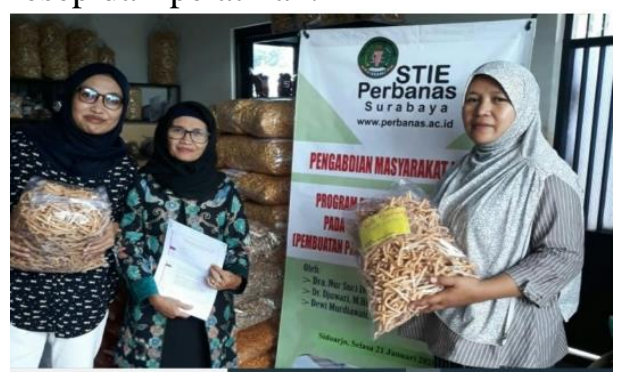

b. Gambar kedua, saat Tim Abdimas menyerahkan cetakan stick kering.

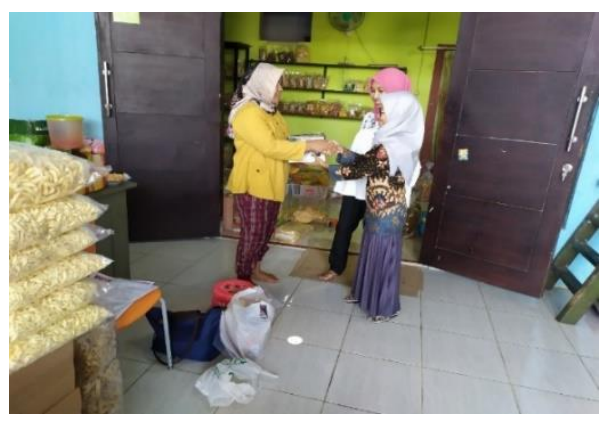

c. Gambar ketiga, pada saat Pelatihan pembuatan stick kering oleh Pelatih.

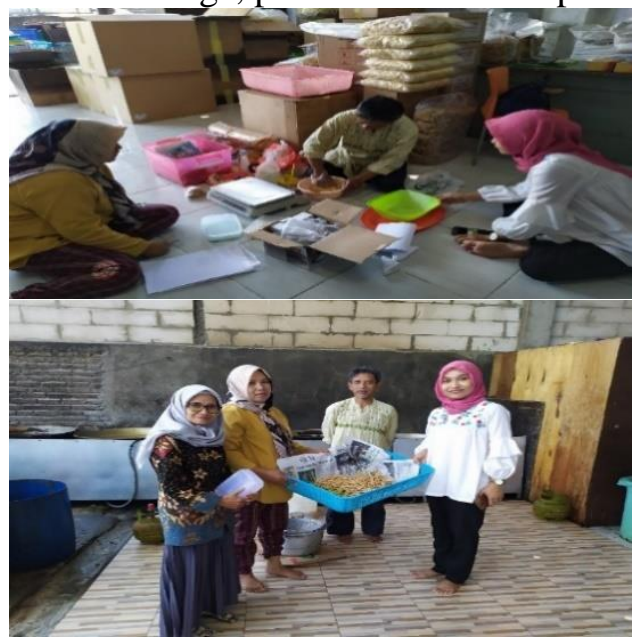


d. Gambar saat Pelatihan Akuntansi
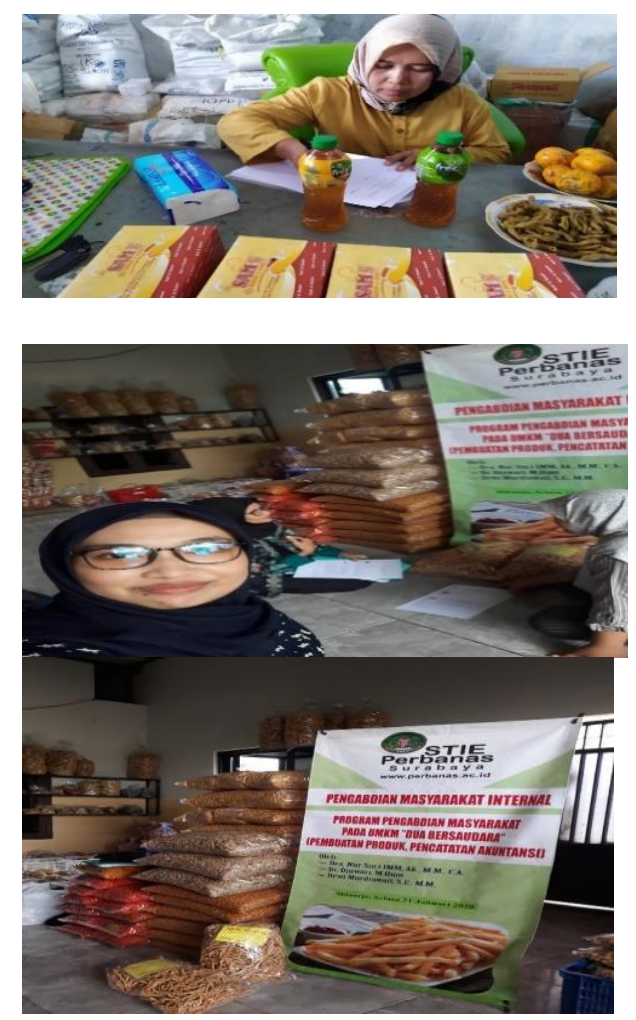

\section{SIMPULAN}

Pelaksanaan program pengabdian kepada masyarakat ini terdapat dua program, yaitu: 1. Pelatihan pembuatan aneka snack stick aneka rasa. 2. Memberikan sharing knowledge dengan memberikan pelatihan tentang pencatatan akuntansi. Manfaat dari kegiatan ini adalah untuk menambah wawasan dan memberikan ketrampilan.

Pada program yang pertama, dalam pelaksanaan pelatihan ini, diberikan pelatihan oleh seorang pelatih yang trampil dalam pembuatan aneka kue kering dan aneka roti. Capaian program yang berhasil dilaksanakan yaitu program yang pertama terlaksana dengan baik sesuai yang telah direncanaka sebelumnya. Perubahan yang dialami oleh mitra setelah program pelatihan ini di antaranya, mitra mendapatkan wawasan baru terkait dengan pembuatan aneka rasa stick kering serta cara atau trik-trik menggoreng agar stick matang secara merata dan tidak menggumpal. Selesai pelatihan, pembuatan stick ini dipraktikkan oleh Mitra dan melakukan produksi serta diikuti dengan pesanan dari pelanggan untuk stick kering ini yang jumlahnya lumayan banyak. Hal ini dirasakan oleh Mitra karena dari sisi rasa dan renyahnya stick yang dihasilkan lebih berkualitas dibanding produk sebelum dilakukan pelatihan. Berikutnya, program yang kedua yaitu pencatatan akuntansi sederhana tidak sampai dilakukan penerapan oleh Mitra, dikarenakan saat itu Mitra sedang fokus kepada pembukaan cabang di kota Banyuwangi dan mendapatkan proyak kegiatan berbagi sembako (sebagai penyedia sekaligus packing) dari lembaga sosial dimana pesanannya jumlahnya cukup banyak.

\section{SARAN}

Adapun saran yang kami berikan adalah bahwa masih banyak sebenarnya masalah atau kendala yang dihadapi Mitra dalam usahanya, sehingga program abdimas untuk mitra ini sebenarnya bisa dikembangkan lagi, misalnya mendampingi dalam pengurusan label "Halal". Berikutnya terkait dengan aplikasi pemasaran secara online juga aplikasi software untuk akuntansinya. Hal yang menjadi catatan adalah pada saat kedua program telah selesai dilakukan, baik pelaksanaan maupun pendampingan, Mitra mengemukakan keinginnanya untuk mengurus dan mendapatkan perizinan Produksi Pangan Industri 
Rumah Tangga (PIRT) dari kota Sidoarjo. Untuk itu kami bantu informasi terkait dengan kelengkapan data yang harus dipenuhi, dan hasilnya UMKM "Dua Bersaudara" telah mendapatkan PIRT dari Sidoarjo.

Program abdimas ini sebenarnya masih bisa dilanjutkan dan dikembangkan untuk program berikutnya, terutama terkait dengan pencatatan akuntansi khususnya pencatatan akuntansi antara kantor pusat dan kantor cabang. Hal ini dikarenakan, UMKM telah membuka cabang di Banyuwangi dan Jember.

\section{UCAPAN TERIMA KASIH}

Keberhasilan pelaksanaan pengabdian kepada masyarakat ini tentunya tidak terlepas dari dukungan dari berbagai pihak, untuk itu, Tim Abdimas mengucapkan terima kasih kepada : 1. Pimpinan STIE Perbanas dan khususnya Koordinator Abdimas (PPPM) yang telah memberikan ijin dan sekaligus memberikan dukungan dana untuk pelaksanaan abdimas ini, 2. Pemilik sekaligus Pimpinan UMKM "Dua Bersaudara" yang memberikan ijin sebagai tempat untuk melakukan pengabdian masyarakat, 3. Pelatih pembuatan snack kering yang telah menyempatkan waktunya memberikan pelatihan dan pendampingan hingga membantu UMKM mendapatkan cetakan dengan kapasitas/skala besar untuk produksi. 4. Serta pihak lain yang tidak secara langsung telah mendukung pelaksanaan program Abdimas ini.

\section{DAFTAR PUSTAKA}

Ikatan Akuntan Indonesia. (2011). Standar Akuntansi Keuangan Entitas Tanpa Akuntabilitas Publik (SAK ETAP). Jakarta: IAI

Ikatan Akuntan Indonesia. (2018). Standar Akuntansi Keuangan Entitas Mikro, Kecil, dan Menengah (SAK EMKM). Jakarta: IAI

Gissel, J. L., \& Johnstone, K. M. (2017). Information sharing during auditors' fraud brainstorming: Effects of psychological safety and auditor knowledge. Auditing: A Journal of Practice \& Theory, 36(2), 87-110.

Kementerian Koperasi dan UKM, 2017.

Liliane, P., \& Colette, G. (2009). Analysis of the dynamics of the sharing knowledge between cooperating teacher and teacher-in-training: The partners' respective roles. Online Submission, 6(6), 71-80.

Mindhayani, I., Lestariningsih, S., \& Susianti, S. (2019). PKM bagi Industri Rumah Tangga di Desa Trimulyo, Kecamatan Jetis, Kabupaten Bantul. Jurnal Ilmiah Padma Sri Kreshna, 1(2).

Saffar, N., \& Obeidat, A. (2020). The effect of total quality management practices on employee performance: The moderating role of knowledge sharing. Management Science Letters, 10(1), 7790.

Santoso, Rudi, Candraningrat dan Binawati, Lilis. 2017. Elemen Kecerdasan Wirausaha Untuk Meningkatkan Kinerja Industri Kecil dan Menengah (IKM) di Surabaya. BISMA (Bisnis dan Manajemen), vol. 1, no. 1, hal. 73-89.

Undang-Undang Nomor 20 Tahun 2008 tentang Usaha Mikro, Kecil, dan Menengah (UMKM). http://www.depkop.go.id/

Warren, Fess, et al. (2015). Akuntansi Pengantar Adaptasi Indonesia. Penerbit Salemba Empat

Zorpas, A. A., Lasaridi, K., Pociovalisteanu, D. M., \& Loizia, P. (2018). Monitoring and evaluation of prevention activities regarding household organics waste from insular communities. Journal of Cleaner Production, 172, 3567-3577. 